удК 346.9

DOI https://doi.org/10.32837/apdp.v0i88.3054

А. О. Калюжна, О. Ю. Поклонська

\title{
ЩОДО ДІЯЛЬНОСТІ ТРЕТЕЙСЬКИХ СУДІВ У ГОСПОДАРСЬКОМУ СУДОЧИНСТВІ
}

Постановка проблеми. Проблематика вивчення нашої роботи полягає в дослідженні діяльності третейських суддів у господарському судочинстві, особливостей провадження у справах, нормативно-правової бази, яка регулює, цю проблему, їхнього правового статусу у сфері господарського права, а також особливостей державного контролю за їхньою діяльністю.

Аналіз наукових досліджень. Це питання в науці господарського права вже вивчалось такими науковцями, як: Т.П. Шепель, С.М. Чагін, М.М. Колотило, О.В. Болтушкіна, М.Д. Мустафаєва, Н.М. Харченко, І.О. Переверзєв та інші. Незважаючи на широку базу нормативно-правової літератури та нормативно правих актів, значний внесок науковців, які вже досліджували це питання, ми вважаємо, що все ж воно потребує детального та подальшого вивчення.

Метою статті є дослідження й аналіз діяльності третейських суддів у господарському судочинстві, їхнього правового становища.

Виклад основного матеріалу. У будь-якому суді, незважаючи на інстанцію, їхню спеціалізацію, територіальне розташування, головним є суддя під час вирішення судових спорів. Суддя, коли здійснює правосуддя, є незалежним та керується верховенством права згідно зі ст. 129 Конституції України. Основними засадами судочинства є: рівність усіх учасників судового процесу перед законом і судом; забезпечення доведеності вини; змагальність сторін та свобода в наданні ними суду своїх доказів і в доведенні перед судом їхньої переконливості; підтримання публічного обвинувачення в суді прокурором; забезпечення обвинуваченому права на захист; гласність судового процесу та його повне фіксування технічними засобами; розумні строки розгляду справи судом; забезпечення права на апеляційний перегляд справи та, у визначених законом випадках, на касаційне оскарження судового рішення; обов'язковість судового рішення [1].

У результаті проведеного аналізу Закону України «Про третейські суди» від 11 травня 2004 р. № 1701-IV [2], на думку I.О. Переверзева, можна виділити окремі відмітні ознаки розгляду третейський спорів:

- законодавче регламентування процедури третейського врегулювання спорів, наявність обов'язкового для сторін внутрішнього регламенту третейського суду, що постійно діє;

- формалізований характер розгляду спорів порівняно з іншими альтернативними способами. У практиці Європейського суду з прав людини третейське судочинство розглядається як форма здійснення правосуддя нарівні з державними судами;

- юрисдикційний характер діяльності третейського суду, арбітром вирішується питання не тільки факту, а й права; 
- виключення із числа спорів, підвідомчих третейському суду, деяких категорій справ. Зокрема, у сфері господарських правовідносин третейським судам не підвідомчі справи у спорах про визнання недійсними нормативно-правових актів; у спорах, що виникають під час укладення, зміни, розірвання та виконання господарських договорів, пов'язаних із задоволенням державних потреб; у спорах, пов'язаних із державною таємницею; про відновлення платоспроможності боржника чи визнання його банкрутом; у спорах, однією зі сторін у яких є орган державної влади, орган місцевого самоврядування, їхня посадова чи службова особа, інший суб'єкт під час здійснення ним владних управлінських функцій на основі законодавства, зокрема й на виконання делегованих повноважень, державна установа чи організація, казенне підприємство; у спорах щодо нерухомого майна, включаючи земельні ділянки; у спорах про встановлення фактів, що мають юридичне значення; у спорах, що виникають із корпоративних відносин між господарським товариством та його учасником (засновник, акціонер), зокрема й учасником, який вибув, а також між учасниками (засновники, акціонери) господарських товариств, пов'язаних зі створенням, діяльністю, управлінням та припиненням діяльності цих товариств, коли хоча б одна зі сторін спору є нерезидентом України; у спорах, за результатами розгляду яких виконання рішення третейського суду потребуватиме вчинення відповідних дій органами державної влади, органами місцевого самоврядування, їхніми посадовими чи службовими особами, іншими суб'єктами під час здійснення ними владних управлінських функцій на основі законодавства, зокрема й на виконання делегованих повноважень [5].

Якщо аналізувати правове значення рішень третейських суддів та з державними судами в господарських справах щодо преюдиційності, то, відповідно до постанови Пленуму Вищого господарського суду України, наприклад, не потребують доказування преюдиціальні обставини, тобто встановлені рішенням суду в господарській, цивільній або адміністративній справі, що набрало чинності, - під час розгляду інших справ, у яких беруть участь ті самі особи або особа, щодо якої встановлено ці обставини. Не має значення, у якому саме процесуальному статусі виступали відповідні особи в таких інших справах - позивачів, відповідачів, третіх осіб тощо. На відміну від цього, обставини, встановлені рішенням третейського суду за Господарським процесуальним кодексом України (далі - ГПК України) та Законом України «Про третейські суди» [2], не мають преюдиціального значення для господарського суду, зокрема і в розгляді ним справи, у якій беруть участь ті самі сторони, що й у третейському провадженні. Господарському суду варто мати на увазі, що третейська угода про передання спору на розгляд третейського суду не є відмовою від права на звернення до суду, а є одним зі способів реалізації права на захист своїх прав. Тобто під час порівняння господарських судів і третейських, щодо визначення доказів преюдиціальними в господарських судах не потребують доказування, на відміну від рішень третейських судів [6].

Варто зазначити, що орган самоврядування третейських суддів, що діє, - Третейська палата України, яка наділена за законом виключно аналітичними і методологічними функціями, у 2018 р., завдяки допомозі програми USAID «Нове правосуддя», наданій через Громадську організацію «Фундація DEJURE”, здійснила 
дослідження стану розвитку третейських судів протягом усієї історії їхнього існування. За цими даними кількість зареєстрованих третейських судів сягає 515 , із яких офіційно припинили діяльність 21 , а з решти лише 248 розглянули бодай одну справу. У 2017-2018 рр. справи розглядали лише 39 третейських судів. Менше 40 третейських судів виконують вимогу закону щодо оприлюднення документів третейського суду - положення, регламенту та списку суддів [9].

Так, у своєму дослідженні С.П. Бондар убачає неефективність та низку популярність звернень до третейських суддів як способу врегулювання господарських спорів, також він розділяє думку В. Коваль, який убачає необхідність усунути суперечність між положенням Конституції України про те, що правосуддя в Україні здійснюється виключно судами і забороняється делегувати функції судів іншим органам, та діяльністю третейських судів, що набуває дедалі більшого поширення. У зв'язку із цим учений запропонував доповнити ст. 124 Конституції України новою частиною: «За згодою учасників господарських відносин допускається вирішення господарських спорів недержавними судовими органами (третейськими, арбітражними тощо), діяльність яких регулюється законом». Водночас така думка не знаходить одностайної підтримки в колах фахівців, адже питання легітимності третейських судів в Україні врегульоване рішенням Конституційного Суду України у справі про досудове врегулювання спорів від 9 липня 2002 р. № 15-рп/2002, за яким встановлення законом чи договором досудового врегулювання спору за волевиявленням суб'єктів правовідносин не є обмеженням юрисдикції судів і права на судовий захист. Тобто сторони спору мають право (можливість) передати справу на розгляд до третейського суду, що не означає виведення справи з юрисдикції державного суду [4].

Варто зазначити, що у 2020 р. вдосконалення законодавства щодо утворення та діяльності третейських судів зазнало позитивних змін. На засіданні Уряду було схвалено проєкт закону України «Про внесення змін до деяких законів України (щодо вдосконалення порядку утворення та діяльності третейських судів з метою відновлення довіри до третейського розгляду)» [3]. Як зазначив Міністр юстиції Д.Л. Малюська, цей законопроєкт має на меті вдосконалити порядок утворення та діяльності третейських судів шляхом посилення вимог до організацій, за яких можуть постійно діяти третейські суди, та розширення повноважень органів третейського самоврядування з метою ефективного здійснення третейського розгляду відповідно до кращих європейських практик. Зокрема, проєктом закону пропонується передбачити таке:

- зміну порядку державної реєстрації третейських судів, а саме визначення Міністерства юстиції України єдиним суб’єктом державної реєстрації третейських судів, що постійно діють. Нині таку функцію, крім Мін'юсту, виконують інші суб’єкти державної реєстрації;

- посилення вимог щодо організацій, за яких можуть утворюватися третейські суди, що постійно діють, а саме визначення, що такі організації мають бути неприбутковими та внесеними до Реєстру неприбуткових установ та організацій, а строк їхньої діяльності від моменту державної реєстрації як юридичної особи до ухвалення рішення про створення третейського суду має становити понад п’ять років; 
- розширення повноважень Третейської палати України, зокрема, до її повноважень буде віднесено встановлення відповідності засновника утворюваного третейського суду, що постійно діє, вимогам Закону, надання відповідного висновку;

- розширення підвідомчості справ, які можуть розглядати третейські суди, шляхом надання права розглядати спори у справах щодо нерухомого майна, а також уточнення компетенції третейського суду в частині розгляду справ у спорах щодо захисту прав споживачів (положення наберуть чинності через три роки із дня набрання чинності цим Законом). Крім того, у розд. II «Прикінцеві та перехідні положення» проєкту закону передбачено здійснення перереєстрації третейських судів, що постійно діють, відповідно до нових вимог Закону. Діяльність третейських судів, що постійно діють, які не звернуться до органу державної реєстрації у встановлений строк, буде припинена в судовому порядку. На нашу думку, цей законопроєкт допоможе третейським судам усунути деякі проблеми під час формування третейського суду, удосконалити їхню діяльність під час розгляду господарських спорів [8].

Доцільно звернути увагу на те, що Верховний Суд (далі - BC) зазначає, що звернення до третейського суду на підставі чинної третейської угоди не є обмеженням права на звернення до господарського суду. Так, наприклад, у справі ТОВ 1 подало позовну заяву про стягнення з ТОВ 2 основної заборгованості, пені, $3 \%$ річних, інфляційних втрат. Позовні вимоги обгрунтовані тим, що відповідач неналежно виконав умови договору про надання транспортних послуг навантажувача щодо повної та своєчасної оплати наданих послуг. Господарський суд позов задовольнив частково (у частині вимог про стягнення пені відмовлено), апеляційний господарський суд його рішення залишив без змін. Суди відмовили в задоволенні клопотання відповідача про припинення провадження у справі з мотивів відсутності волі обох сторін про передачу спору третейському суду та неможливості позбавлення позивача конституційного права на звернення до господарського суду. Касаційний господарський суд ВС постановою у справі № 913/783/17 рішення судів попередніх інстанцій скасував, а позов залишив без розгляду. Суд дійшов висновку, що доводи відповідача про порушення судом першої інстанції приписів ст. 80 ГПК України (у редакції, чинній до 15 грудня 2017 р.) та судом апеляційної інстанції - приписів ст. 226 ГПК України (у редакції, чинній з 15 грудня 2017 р.) є обгрунтованими з огляду на таке рішення. Предметом спору в цій справі є стягнення з відповідача заборгованості за неналежне виконання ним своїх зобов'язань за договором. Сторони в договорі визначили, що всі спори, які виникають між сторонами у зв'язку з виконанням цього договору або що стосуються його зміни, припинення, недійсності, підлягають розгляду, і кожен конкретний спір вирішується у третейському суді (третейський суд “ad hoc”). Отже, між сторонами є третейська угода про передачу всіх спорів на вирішення третейського суду, яка недійсною не визнавалась і відповідає вимогам ст. 12 Закону України «Про третейські суди», а тому є обов’язковою до виконання, до того ж відповідач наполягав та наполягає на вирішенні спору саме третейським судом [7].

Висновки. У результаті проведеного аналізу даної теми ми конкретизовано визначили діяльність третейських судів у господарському судочинстві та дійшли 
висновку, що вони є окремим, недержавним видом юрисдикції із пріоритетом захисту приватних (а не переважно публічних) порушених прав та інтересів сторін у справах, що здійснюється в межах прав, визначених Конституцією України. Рішення цих судів також мають юридичну силу та виконуються органами державної виконавчої служби в порядку, встановленому для рішень судів загальної юрисдикції. Водночас на практиці звернення до цього суду як до способу розв'язання господарських спорів серед суб'єктів відповідних правовідносин є малоефективними, на що вказують статистичні данні.

\section{Jimepamypa}

1. Конституція України : Закон від 26 червня 1996 р. Відомості Верховної Ради України. 1996. № 30. Ст. 141 URL: https://zakon.rada.gov.ua/laws/main/254к/96-вр (дата звернення: 10.11.2020).

2. Про третейські суди : Закон України від 5 жовтня 2016 р. Відомості Верховної Ради України. 2004. № 35. Ст. 412. URL: https://zakon.rada.gov.ua/laws/show/1701-15\#Tехt (дата звернення: 10.11.2020).

3. Про внесення змін до деяких законів України (щодо вдосконалення порядку утворення та діяльності третейських судів з метою відновлення довіри до третейського розгляду) : Закон України. URL: http://w1.c1.rada.gov.ua/pls/zweb2/webproc4_2?pf3516=3045-1\&skl=10 (дата звернення:10.11.2020).

4. Бондар С.П. Розвиток та правове забезпечення третейського судочинства в системі господарського судочинства. URL: http://uf.tneu.edu.ua/wp-content/uploads/2020/03/Ternopil-TNEUConf-2019.pdf\# page $=36$.

5. Переверзев I.О. Третейське судочинство у сфері господарської діяльності: проблеми застосування та шляхи вирішення. Форум права. 2017. URL: file:///C:/Users/User/Downloads/298-304-2017-5ФП\% 20Переверзєв \% 20(47).pdf.

6. Про деякі питання практики застосування Господарського процесуального кодексу України судами першої інстанції : постанова Пленуму Вищого господарського суду України. URL: https:// zakon.rada.gov.ua/laws/show/v0018600-11\# top (дата звернення: 10.11.2020).

7. Практика. Звернення до третейського суду на підставі дійсної третейської угоди не є обмеженням права на звернення до господарського суду - Верховний Суд. URL: https://supreme.court.gov.ua/ supreme/pres-centr/news/646795/ (дата звернення: 10.11.2020).

8. Уряд схвалив законопроєкт щодо вдосконалення порядку утворення та діяльності третейських судів. URL: https://www.kmu.gov.ua/news/uryad-shvaliv-zakonoproekt-shchodo-vdoskonalennyaporyadku-utvorennya-ta-diyalnosti-tretejskih-sudiv (дата звернення: 10.11.2020).

9. Третейські суди в Україні, стан розвитку, статистика, практика та перспективи / Т.П. Шепель. Київ, 2018. URL: https://newjustice.org.ua/wpcontent/uploads/2019/02/New_Justice_Analytical_ Report_Arbitration_Courts_in_Ukraine_UKR.pdf.

\section{Анотація}

Калюжна $A$. О., Поклонська О. Ю. Щодо діяльності третейських судів у господарському судочинстві. - Стаття.

$\mathrm{y}$ науковій статті під час дослідження питання у сфері господарського судочинства передусім зосереджено увагу на знаходженні істини в порушених правовідносинах, вирішенні конфліктів, спорів, які виникають між суб'єктами та взагалі. Здійснення правосуддя в Україні належить виключно судам. У нашій державі судова система перебуває на досить високому та професійному рівні. Становлення системи судоустрою з історичного погляду почалося з найдавніших часів княжої доби та мало таку структуру: княжий суд, вічевий суд, громадський, або народний суд, приватні землевласні суди та церковні суди. Після розпаду Радянського Союзу в нашій незалежній державі Україні почала формуватися судова влада, за весь час незалежної України було чотири судові реформи. На сучасному етапі в Україні положення щодо судоустрою регулюється Законом України «Про судоустрій та статус суддів» від 2 червня 2016 року № 1402-VIII та Конституцією України. Систему судоустрою становлять суди загальної юрисдикції та Конституційний Суд. Найвищим судом у системі правосуддя є Верхов- 
ний Суд. Згідно з Конституцією України, третейські суди не входять до системи загальної юрисдикції. Діяльність третейських судів на території України регулює Закон України "Про третейські суди» від 11 травня 2004 року № 1701-IV. Варто зазначити, що даний Закон регулює порядок утворення та діяльності третейських судів в Україні та встановлює вимоги щодо третейського розгляду з метою захисту майнових та немайнових прав і охоронюваних законом інтересів фізичних і юридичних осіб. До третейського суду за угодою сторін може бути переданий будь-який спір, що виникає із цивільних та господарських правовідносин, крім випадків, передбачених законом. Також акцентовано увагу на вдосконаленні законодавства щодо діяльності третейських судів у 2020 році, що полягає у внесенні змін до деяких законів України щодо вдосконалення порядку створення та діяльності третейських судів, що має на меті відновлення довіри до третейського розгляду. На підставі системного аналізу досліджених матеріалів зазначеної проблематики дійшли висновку, що, незважаючи на законодавче врегулювання діяльності третейських судів, усе ж таки у практичній діяльності звернення до даного інституту не є популярним, що доводить статистика.

Ключові слова: суд, правосуддя, суддя, третейський суд, господарське судочинство.

\section{Summary}

Kaliuzhna A. O., Poklonska $\mathrm{O}$. Yu. On the activities of arbitratory courts in commercial judicial procedure. - Article.

The research article in the field of commercial litigation focuses primarily on finding the truth in violated legal relations, resolving conflicts, disputes that arise between certain entities and in general: the administration of justice in Ukraine belongs exclusively to the courts. In our country, the judicial system is at a fairly high and professional level. The formation of the judicial system from the historical point of view began in ancient times of the princely era and had the following structure: princely court, chamber court, public or people's court, private land courts and ecclesiastical courts. After the collapse of the USSR in our independent state of Ukraine, the judiciary began to form, during the whole period of independent Ukraine there were four judicial reforms. At the present stage in Ukraine, the provisions on the judiciary are regulated by the Law "On the Judiciary and the Status of Judges" of 02.06.2016 № 1402-VIII and the Constitution of Ukraine. The judicial system consists of courts of general jurisdiction and the Constitutional Court. The highest court in the justice system is the Supreme Court. According to the Constitution of Ukraine, arbitration courts are not part of the system of general jurisdiction. The activity of arbitration courts on the territory of Ukraine is regulated by the Law of Ukraine "On Arbitration Courts" of 11.05.2004 № 701701-IV. It should be noted that this Law regulates the formation and operation of arbitration courts in Ukraine and establishes requirements for arbitration in order to protect property and non-property rights and legally protected interests of individuals and legal entities. Any dispute arising from civil and commercial legal relations may be referred to an arbitral tribunal by agreement of the parties, except in cases provided by law. Also, attention is focused on improving the legislation on arbitration in 2020 , which is to amend some laws of Ukraine to improve the formation and operation of arbitration, which in turn aims to restore confidence in arbitration. Based on a systematic analysis of the studied materials on this issue, it was concluded that despite the legislative regulation of the arbitration courts, still in practice, recourse to this institution is not popular, according to statistics.

Key words: court, justice, judge, arbitration court, commercial litigation. 